\title{
The Effects of Ownership Types, Concentration, and Foreign Banks' Modes of Entry Risk-Taking Behaviour and Capital Ratio
}

\author{
Karinna ${ }^{1}$ and Viverita ${ }^{2}$ \\ Department of Management, Faculty of Economics and Business, Universitas Indonesia, \\ Indonesia $^{1,2}$ \\ ${ }^{1}$ Karinna1896@gmail.com, ${ }^{2}$ viverita.d@ui.ac.id
}

\begin{abstract}
This paper examines the effect of ownership types and concentration, as well as the impact of foreign bank's entry modes on bank's risk-taking behavior and capital ratio and also analyze the effect of bank-risk taking behavior and capital ratio have to one another simultaneously. This study uses panel data of 87 banks in Indonesia and Malaysia from 2003 to 2016. This study finds that government-owned bank and foreign-owned banks take more risk and have higher capital ratio compared to the privately-owned bank, while foreign banks that enter the market with merger $\&$ acquisition strategy tends to take less risk than those who enter the market with greenfield strategy.Moreover, the result also shows that bank-risk taking behavior and the capital ratio has negative effects on one another and that banks take less risk and hold more capital during the financial crisis period. These findings have major implications towards government's and foreign ownership limitations such as limiting the number and entry of foreign and state ownership will be effective to reduce bank-risk taking behavior and implementing minimum capital adequacy policies will be able to initiate less-aggressive risk-taking behavior.
\end{abstract}

Keywords: Bank risk, Capital ratio, Ownership types, Ownership concentration, Capital regulation, Foreign bank entry

\section{Introduction}

The Asian Financial Crisis in 1997/1998 has a profound effect on almost all countries in Southeast Asia and resulted in several bank's restructuring policies. Indonesia in particular decided to roll out several policies to reduce the number of banks in the country to create a safeguard for banks to help them survive the financial crisis through the minimum capital adequacy ratio policy. Both Indonesia and Malaysia have implemented $8 \%$ minimum capital adequacy ratio, quite different from other Southeast Asian countries which mostly implemented higher capital ratio. Moreover, both Indonesia and Malaysia have the $2^{\text {nd }}$ and $3^{\text {rd }}$ highest ownership concentration level in Southeast Asia and the state-owned banks in both countries dominated the banking industry in terms of asset despite only having small number of state-owned banks. Taking the similarities in both the banks ownership characteristics and 
policies implementation, Indonesia and Malaysia seem fit to be used as samples in this study. However, the high capital al ratio does not automatically mean a reduction in bank-risk, as previous studies has proven otherwise. Based on regulatory hypotheses, banks would increase their risk along with the increase in their capital ratio [1]. If the regulatory hypothesis holds, then the government plan to reduce bank-risk using a minimum capital adequacy ratio policy would backfire. Although other researches show different result, motivated by the moral hazard theory. This is one of the fundamental reasons why this research is deemed necessary.

Another significant implication from the policies enacted after the financial crisis is the rise of foreign-owned banks and the domination of state-owned banks in both Indonesia and Malaysia. State-owned banks in Malaysia represent about $40 \%$ of the banking industry's total asset while in Indonesia, it represents around 38,7\% in 2016. Foreign-owned banks also dominated the banking industry regarding the number of banks in Malaysia. State-owned banks have been proven to be more inefficient compared to another type of banks due to their political ties with the government and the complicated bureaucracy (Lassoued, Sassi, Ben, \& Attia, 2016) but they still give loans more than any other banks (Indonesia Statistics Institution, 2016), thus, increasing their credit risk. Foreign-owned bank's participation also rises rapidly in the following years after the financial crisis, while most studies show that foreign-owned banks usually take more risks due to their disadvantages in acquiring comprehensive information like private-owned or state-owned banks [2] The notion that both state-owned banks, which dominated the banking industry, and foreign-owned banks, which show rapid growth in the last few years, to take more risk compared to private-owned banks could pose as a threat to the banking industry.

Foreign bank's mode of entry also shows different behavior in risk-taking, as banks which enter the market via merger \& acquisition might get influenced by the domestic banks it acquired or merged with [2]; [3]. While talking about ownership, we also have to acknowledge that type of ownership is not the only factor that might influence bank's risktaking behavior and capital ratio policies; ownership concentration has also been the focus of many studies, starting with [4] The agency theory, formulated by Jensen \&Meckling, [4]provides insight about how shareholders tend to focus on revenue while managers who face the threat of losing their job prefer to contain and limit bank risks. Based on the agency theory, banks with concentrated ownerships usually take more risks, as supported by previous studies such as Chalermchatvichien [5] and Eisenhardt, [6]The interesting part about this research also lies in the effect that bank-risk taking behavior and the capital ratio has one another, which means that both variables are endogenous variables and require two-step simultaneous least square regression (2SLS) testing.

This study contributes to the existing bank-risk taking and capital ratio literature with a focus on the banking industry in Indonesia and Malaysia. The findings show that capital ratio and bank-risk taking behavior indeed have an adverse bi-directional effect towards one another, which means that an increase in capital ratio will be effective to reduce bank's risktaking, as intended by the Basel Committee and the government of both countries[7] Furthermore, this study also proves that government-owned banks and foreign-owned banks take more risks and has higher capital ratio compared to private-owned banks, which means that policies to reduce or put a limit to both state and foreign banks to be created or enter the market might help to reduce the overall risk in Indonesia and Malaysia banking industry. Moreover, this study also examines the effect of foreign bank's entry modes on risk-taking behavior and capital ratio. The result shows that banks which enter the market via M\&A take fewer risks than other entry mechanisms. This finding is in accordance with the asymmetric information theory and could help the government to control the mode of entry for foreign banks in the future. Also, during the global financial crisis period, banks in Indonesia and 
Malaysia also tend to have less aggressive risk-taking behavior, to control their risk-level and avoid insolvency while taking the initiative to have a higher capital ratio as a safety measure. The rest of this paper is presented as follows. Section 2 will provide a brief explanation on literature review, which includes theory that will be tested and previous studies. Section 3 will describe the model and methodology used on this research. Section 4 presents the results and give brief analysis based on those results, and section 5 will give a summary and some recommendations.

\section{Literature Review And Hypotheses Development}

Studies in bank-risk taking behavior have become a crucial part of researches in the banking industries. There are two main theories on the relationship between bank risk-taking behavior and capital ratio, i.e., the regulatory hypotheses and moral hazard theory. Regulatory hypothesis explains that regulators push banks to increase their capital by the increase the risklevel [8]; [9]

On the other hand, the moral hazard theory explains that capital ratio will affect bank-risk taking behavior negatively due to the availability of a deposit insurance scheme. When deposit insurance is provided, banks will be inclined to reduce their risks when their capital ratio increases. Since the incentives, they receive from deposit insurance decreases, and they have to cover their risks with their capital. The tendency to increase risks to reap benefits from deposit insurance cause moral hazard behavior. Based on the theories and previous studies, these are the hypotheses developed:

H1a: Bank risk taking behavior has a negative effect on capital ratio

H1b: Capital ratio has a negative effect on bank risk-taking behavior

Regarding the type of ownership, banks categorized into three types, state-owned banks, foreign-owned banks, and private-owned banks. Based on the political theory, state-owned banks have the highest inefficiency level due to political intervention and government bureaucracy [10];[11] Shleifer \&Vishny Previous studies also prove that banks with political connection have higher chance to be rescued by the government in case of insolvency[12] Similarly, foreign-owned banks have also been proven to take more risks compared to privateowned banks due to asymmetric information issues, causing foreign-owned banks to be at a disadvantage due to unavailability of information regarding the clients and the local banking industry itself. Moreover, due to the rapid growth and high profitability of the banks in Indonesia and Malaysia, foreign-owned banks are willing to take more risks in return of high benefits in the future [12]; [13]; [14]

Specifically, foreign-owned banks can be classified into two categories based on their mode of entry, by merger \& acquisition and by greenfield investment. According to asymmetric information theory, banks who enter the market via merger \& acquisition will have an advantage regarding acquiring information, regulation and market-wise, from the banks they acquired or merged with [15]; [2]). In contrast, [16]also mention that banks who enter via greenfield investment would be easier to monitor by the managers from home country compared to those who enter via M\&A. Moreover, managers in banks who merged with local banks, may have their agenda and increase the agency problems within the company, thus increasing the risks. Therefore, based on the theories and studies by [14]; [17]; [15]; [10], state-owned and foreign-owned banks are expected to have negative sign on ZScore or positive sign on bank risk-taking behavior while foreign bank's mode of entry using 
merger \& acquisition is predicted to have a positive sign on Z-Score and negative sign on bank risk-taking behavior. The hypotheses generated are as follow:

H2: State-owned banks take higher risks compared to private-owned banks

H3: Foreign-owned banks take higher risks compared to private-owned banks

H4: Foreign bank's mode of entry has an effect on bank's risk takingbehaviour

Indonesia and Malaysia are also the 2nd and 3rd highest ownership concentration countries in Southeast Asia. Banks with high ownership concentration indicate a higher power of shareholder compared to managers. According to the agency theory, shareholders have the tendency to take more risks to increase their future revenue due to their ability to diversify their portfolio, thus reducing their portfolio risks while managers prefer to take more moderate stance on risk-taking since they have to ensure their position within the company due to their inability to diversify their jobs [4]Other contradictory views said that shareholders would be more involved and would increase their monitoring towards managers so managers wouldn't be able to pursue personal benefits, this view shows that ownership concentration has an adverse effect on bank-risk taking behavior. Based on the explanations mentioned in the agency theory, the hypotheses generated is as follow:

\section{H5: Ownership concentration has a positive effect on bank-risk taking behavior}

Aside from bank-risk taking behavior, this study also focuses on the bank's capital ratio. State-owned banks tend to have higher capital ratio level as they usually have more assets and broader clients network, which indicates their needs to be more careful due to higher responsibility [15]; [10] Foreign-owned banks, in contrast, have more access to international investors and capital markets would be able to increase their capital easier compared to domestic private-owned banks [17]Based on the concentration views, banks with high ownership concentration has been proven to have a lower capital ratio level [18] However, other studies have proven otherwise, where banks with highly concentrated ownership indicate that the shareholder will have higher stakes within the company and get more motivated to monitor the manager, one of which is through capital ratio policy [19]; [20]According to previous studies as explain above, these are the hypotheses created:

H6: State-owned and foreign-owned banks has higher capital ratio compared to private-owned banks

H7: Ownership concentration has positive effect on bank's capital ratio

This study will also include the period of financial crisis in $2008-2010$, which leads us to also put a focus on the crisis period. During the crisis, banks which enjoy the benefits of deposit insurance will take fewer risks as deposit insurance will do its job to stabilize the banking industry or using its "stabilizing effect" [21]Similarly, the previous study in Indonesia also finds that during the crisis period, the existence of deposit insurance system will be able to reduce systemic risk in the banking industry, fulfilling the objective of deposit insurance itself [22]Also in accordance with the moral hazard theory, during the crisis with rising tension and possibility of failure, banks would prefer to utilize the deposit insurance provided by the government, rather than using their own capital as a safeguard, therefore, a bank's 
capital ratio is predicted to decline during the financial crisis period [21]. The hypotheses generated for the effect of crisis are as follow:

H8a: Banks tend to take less risks during the financial crisis period

H8b: Banks tend to reduce capital ratio during the financial crisis period

Based on the literature review and previous researches, the table below shows the expected sign of each independent variables towards dependent variables. The proxy used for bank-risk taking behavior is Z-Score, which means that the higher the Z-Score is, the lower risks taken by banks, thus the sign expected for Z-Score will have a negative effect on bank risk-taking behavior.

Table 2.1: Expected Sign from Independent Variables

\begin{tabular}{|c|c|c|c|}
\hline \multicolumn{2}{|c|}{$\begin{array}{c}\text { Dependent Variable : } \\
\text { Z-Score (Bank Risk- } \\
\text { taking) }\end{array}$} & \multicolumn{2}{|c|}{$\begin{array}{c}\text { Dependent Variable : } \\
\text { CAR (Capital Ratio) }\end{array}$} \\
\hline $\begin{array}{c}\text { Independent } \\
\text { Var }\end{array}$ & $\begin{array}{c}\text { Sig } \\
\mathrm{n}\end{array}$ & Independent Var & Sign \\
\hline Capital Ratio & + & Z-Score & + \\
\hline $\begin{array}{c}\text { Foreign-Owned } \\
\text { Banks }\end{array}$ & - & $\begin{array}{c}\text { Foreign-Owned } \\
\text { Banks }\end{array}$ & + \\
\hline $\begin{array}{c}\text { State-Owned } \\
\text { Banks }\end{array}$ & - & $\begin{array}{c}\text { State-Owned } \\
\text { Banks }\end{array}$ & + \\
\hline $\begin{array}{c}\text { Mode of Entry } \\
\text { (M\&A) }\end{array}$ & + & $\begin{array}{c}\text { Mode of Entry } \\
\text { (M\&A) }\end{array}$ & + \\
\hline $\begin{array}{c}\text { Active } \\
\text { Shareholder }\end{array}$ & - & $\begin{array}{c}\text { Active } \\
\text { Shareholder }\end{array}$ & + \\
\hline Passive & + & $\begin{array}{c}\text { Passive } \\
\text { Shareholder }\end{array}$ & - \\
\hline Shareholder & & $\begin{array}{c}\text { Risk Weighted } \\
\text { Asset to Total } \\
\text { Asset }\end{array}$ & - \\
\hline Leverage & - & Return on Total \\
Asset & + \\
\hline Size & + & Asset Growth & + \\
\hline Inflation & + & Size & - \\
\hline GDP Growth & - & Inflation & - \\
\hline Crisis & + & GDP Growth & - \\
\hline & & Crisis & - \\
\hline
\end{tabular}

\section{Research Methodology}

This study tested the data from all conventional commercial banks in Indonesia and Malaysia for the period of 2003 - 2016 and employed total of 87 banks, with 71 of those coming from Indonesia and 16 banks from Malaysia. The odd numbers for the samples are caused by a lack of data for Banks in Malaysia, as not all banks publish their financial/annual report. The bank-risk taking behavior represents by Z-score, and the data for the capital ratio is represented by the capital adequacy ratio (CAR). All bank-level data including both main 
variable and control variables are collected from financial reports published by OtoritasJasaKeuangan (OJK) in Indonesia and from respective banks annual financial report in Malaysia, hence, the author was having difficulty to collect the data for banks in Malaysia, resulting in a small number of banks in Malaysia. Country-level data collected from central banks in both countries (Bank Indonesia and Bank Negara Malaysia) and the World Bank's website.

\section{a. Model Specification}

Several proxies have been used in the past to explain bank-risk taking behavior, as bank risk has several dimensions, from credit risk, operational risk, market risk, or solvency risks. In this paper, we use insolvency risk to explain bank risk-taking behavior, using Z-score as a proxy, which shows bank's distance to insolvency risks, which means that the higher the value of Z-score, the less insolvency risk associates with the bank. The value of z-score can be calculated by adding the value of return on the asset with capital to asset ratio and dividing it with the standard deviation of return on the asset as used by previous studies [9]; [23]The main variables used to explain bank-risk taking includes ownership type, which uses dummy variables that indicate whether the bank is state-owned, foreign-owned, or private-owned based on the share of the bank's largest shareholder which has to exceed $50 \%$ to be included in one of the categories. Also, this study also measures the foreign bank's entry mode using the dummy variable to represent foreign banks that enter the market via merger $\&$ acquisition or greenfield investment. Other main variable is ownership concentration which use the interaction of the share of largest shareholder with a dummy variable that indicates whether a bank has passive shareholder (PS) if the largest shareholder owns less than $20 \%$ share in the company, active minority shareholder (MAS) for 20\%-50\% ownership or active shareholder (AS) for more than $50 \%$ ownership

Bank-risk taking model uses leverage, which indicates how much loans that bank use to finance or to support its asset, bank size, to shows the difference between a bank with large asset and banks with small assets. While capital ratio model uses bank size as well, with some additional bank-level variables like weighted risk asset to total asset ratio to show the amount of risky asset compared to total asset, return on the asset as the proxy for profitability, and asset growth. Both variables also use macroeconomic-level control variables like GDP growth and Inflation rate. Following previous studies by [24]; [25]this study will also use simultaneous regression or 2SLS to be able to analyze the effect that bank risk-taking behavior and capital ratio have to one another. Therefore, to examine the influence of ownership type, structure and foreign bank's entry mode towards bank risk-taking behavior and capital ratio these are the model used in this study:

$$
\begin{aligned}
R I S K_{i, j, t}=\alpha_{0}- & \alpha_{1} C A P_{i, j, t}+\alpha_{2} O S_{i, j, t} \\
& +\alpha_{3} O T_{i, j, t} \\
& -\alpha_{4} S I Z E_{i, j, t} \\
& +\alpha_{5} L E V E R A G E_{i, j, t} \\
& -\alpha_{6} 7 G G D P_{j, t} \\
& +\alpha_{7} I N F R_{j, t}+\varepsilon_{i, j, t}
\end{aligned}
$$




$$
\begin{aligned}
\text { RISK }_{i, j, t}=\alpha_{0}- & \alpha_{1} \operatorname{CAP}_{i, j, t}+\alpha_{2} O S_{i, j, t} \\
& +\alpha_{3} O T_{i, j, t} \\
& -\alpha_{4} \operatorname{SIZE}_{i, j, t} \\
& +\alpha_{5} \operatorname{LEVERAGE}_{i, j, t} \\
& -\alpha_{6} 7 G G D P_{j, t} \\
& +\alpha_{7} \operatorname{INFR}_{j, t} \\
& +\alpha_{8} \operatorname{CRISIS}_{t}+\varepsilon_{t}
\end{aligned}
$$

In equation 3.1, bank-risk taking behavior, proxy by ln Z-Score, is regressed with capital adequacy ratio. The ownership type includes three dummy variables to represent state-owned, foreign-owned and private-owned banks. Moreover, the ownership concentration categorizes into an active shareholder, active minority shareholder, and passive shareholder, while control variables are size, leverage with GDP growth and inflation rate represent macroeconomiclevel control variable. Model 3.2 also looks at the effect of financial crisis period to bank-risk taking behavior while Model 3.3 specifically look at the impact of foreign bank's entry mode, which is represented by a dummy variable for merger \& acquisition and greenfield investment methods. However, to identify the effect of foreign bank's entry mode, we have to create a separate model and include a new dummy variable to indicate whether a foreign bank enters a market via merger \& acquisition or greenfield investment while the rest of the variables stays the same.

$$
\begin{aligned}
\operatorname{RISK}_{i, j, t}=\alpha_{0}- & \alpha_{2} \operatorname{CAP}_{i, j, t}+\alpha_{3} O S_{i, j, t} \\
& +\alpha_{4} O T_{i, j, t}+\alpha_{5} M E_{i, j, t} \\
& -\alpha_{6} S I Z E_{i, j, t} \\
& +\alpha_{7} L E V E R A G E_{i, t} \\
& -\alpha_{8} 7 G G D P_{j, t} \\
& +\alpha_{9} I N F R_{j, t}+\varepsilon_{i, j, t} \\
\operatorname{RISK}_{i, j, t}=\alpha_{0}- & \alpha_{2} \operatorname{CAP}_{i, j, t}+\alpha_{3} O S_{i, j, t} \\
& +\alpha_{4} O T_{i, j, t}+\alpha_{5} M E_{i, j, t} \\
& -\alpha_{6} S_{Z I E_{i, j, t}} \\
& +\alpha_{7} L E V E R A G E_{i, j, t} \\
& -+\alpha_{8} 7 G G D P_{j, t} \\
& +\alpha_{9} I N F R_{j, t} \\
& +\alpha_{10} C \operatorname{RISIS} S_{t}+\varepsilon_{i, j, t}
\end{aligned}
$$

The variable ME (Mode of Entry) examines the effect of the Bank's mode of entry on bank-risk taking behavior. Banks that enter a market via merger \& acquisition will have an advantage regarding the information acquired. Furthermore, model 3.4 is used to check the consistency of bank risk-taking behavior and capital ratio during the crisis period. The fifth model (Model 3.5) examines the effect of capital ratio along with, as the ownership type, ownership structure on bank-risk taking behavior. Hence, making bank risk and capital ratio to be endogenous variable, and other control variables such as risk-weighted asset to total asset ratio (RWATA), asset growth (AG) and Return on Asset (ROA) along with both macroeconomic variables, GDP growth, and inflation rate. 


$$
\begin{aligned}
C A P_{i, j, t}=\beta_{0}- & \beta_{2} R I S K_{i, j, t}+\beta_{3} O S_{i, j, t} \\
& +\beta_{4} O S_{i, j, t} \\
& -\beta_{5} S_{Z I E_{i, j, t}} \\
& +\beta_{6} R O T A_{i, j, t} \\
& -\beta_{7} R W A T A_{i, j, t} \\
& +\beta_{8} A G_{i, j, t}-\beta_{9} G G D P_{j, t} \\
& -\beta_{10} I N F R_{j, t}+\varepsilon_{i, j, t} \\
C A P_{i, j, t}=\beta_{0}- & \beta_{2} R I S K_{i, j, t}+\beta_{3} O S_{i, j, t} \\
& +\beta_{4} O S_{i, j, t} \\
& -\beta_{5} \operatorname{SIZE}_{i, j, t} \\
& +\beta_{6} \operatorname{ROTA}_{i, j, t} \\
& -\beta_{7} R W A T A_{i, j, t} \\
& +\beta_{8} A G_{i, j, t} \\
& -\beta_{9} G G D P_{j, t} \\
& -\beta_{10} I N F R_{j, t} \\
& -\beta_{11} \operatorname{CRISIS}_{t}+\varepsilon_{i, j, t}
\end{aligned}
$$

The sixth model, quite similar with the second and fourth model, is developed to analyze bank's capital ratio during the crisis period $(2008-2010)$ with the same control variables used in the previous model. However, during the testing for model $1 \mathrm{a}, 1 \mathrm{~b}, 2 \mathrm{a}$, and $2 \mathrm{~b}$, this study will exclude return on the asset from the instrument list as it might act as an endogenous variable that correlates with bank-risk taking behavior.

\section{Results And Analysis}

This part presents the findings and the analysis from the testing using simultaneous regression for all the three models.

\section{a. Descriptive Statistics}

Table 1 shows the descriptive statistics for all variables used in this study. As previously explained, this study uses panel data of 87 banks operated in Indonesia and Malaysia for the period of $2003-2016$. Overall, this study uses the total of 1215 observations over 14 years period. The Table below shows the summary for all variables.

Table 4.1: Summary Statistics

\begin{tabular}{ccccc}
\hline Variables & Mean & $\begin{array}{c}\text { St. } \\
\text { Dev }\end{array}$ & Min & Max \\
\hline lnzscore & 3.518 & 1.285 & -3.838 & 7.64 \\
& & & & 0 \\
CAR & 0.254 & 0.225 & -0.143 & 2.91 \\
& & & & 3 \\
Foreign & 0.447 & 0.497 & 0 & 1 \\
$\begin{array}{c}\text { StateOwne } \\
\text { d }\end{array}$ & 0.118 & 0.322 & 0 & 1 \\
MAS & 0.086 & 0.159 & 0 & 0.49 \\
& & & & 9
\end{tabular}




\begin{tabular}{|c|c|c|c|c|c|}
\hline AS & 0.60 & & 0.400 & 0 & 1 \\
\hline MA & 0.17 & & 0.382 & 0 & 1 \\
\hline Crisis & 0.14 & & 0.350 & 0 & 1 \\
\hline Leverage & 0.85 & & 0.122 & - & 1.27 \\
\hline ROA & 0.01 & 183 & 0.0631 & -1.286 & $\begin{array}{c}1.54 \\
0\end{array}$ \\
\hline AG & 0.20 & 01 & 0.352 & -0.628 & $\begin{array}{c}6.31 \\
2\end{array}$ \\
\hline RWATA & 0.65 & & 0.182 & -0.702 & $\begin{array}{c}1.82 \\
0\end{array}$ \\
\hline GGDP & 0.05 & 542 & 0.0121 & $\begin{array}{c}- \\
0.0253\end{array}$ & $\begin{array}{c}0.09 \\
4\end{array}$ \\
\hline INFL & 0.07 & 745 & 0.0477 & $\begin{array}{c}- \\
0.0502\end{array}$ & $\begin{array}{c}0.18 \\
1\end{array}$ \\
\hline $\begin{array}{c}\text { No. } \\
\text { Observatio } \\
n\end{array}$ & \multicolumn{3}{|c|}{$\begin{array}{ll}5 & \text { Sample } \\
& \text { Indonesia }\end{array}$} & 71 & \\
\hline $\begin{array}{l}\text { No. of } \\
\text { Banks }\end{array}$ & 87 & \multicolumn{2}{|c|}{$\begin{array}{l}\text { Sample } \\
\text { Malaysia }\end{array}$} & 16 & \\
\hline
\end{tabular}

Most of the Indonesian and Malaysian banks have highly concentrated ownership as both countries listed as the 2nd and 3rd countries with the highest ownership concentration level in Southeast Asia. The mean and the standard deviation for ln Z-Score of banks in both counties is quite similar with previous studies in Asia [24]; [25]However, the value of standard deviation is high due to the different characteristics in the two countries used as samples. Other main variables, Capital Adequacy Ratio shows that the lowest value in the observations is recorded by Just bank in 2008 when the bank failed due to liquidity problems that lead to insolvency. Moreover, this study also uses various control variables such as leverage which has the average value of 0,856 which explains that banks in Indonesia and Malaysia still use loans to finance its assets compared to equity, where around $85 \%$ of bank's total asset is supported by liabilities. Return on Asset in this study also shows a similar result with previous studies, as does its asset growth and the risk-weighted asset to total asset ratio. Lowest values for both variables are also shown by Jtrust Bank in 2008. Also, the negative inflation rate is recorded by Malaysia in 2009 with 5,02\% inflation rate, calculated with GDP deflator.

\section{b.Empirical Results}

The purpose of this study is to analyze the effect of ownership types, concentration and foreign bank's entry modes on bank risk-taking behavior and capital ratio. Also, it aims to investigate the impact of bank risk-taking behavior and capital ratio on one another. Due to the endogenous trait of bank risk-taking behavior and capital ratio, this study uses the simultaneous regression method or 2SLS with random effects model, so the violations for a classic assumption do not change the results for the regression result. The results shown by Table 2 confirm hypotheses $1 \mathrm{a}$ and $1 \mathrm{~b}$. We find that capital ratio has a negative effect on bank risk-taking behavior, supporting the moral hazard theory [21]; [23] When the bank increases their capital ratio, the incentives they received from deposit insurance, the protection provided by the government in case of insolvency, also decreases since they can't depend on the 
coverage provided by deposit insurance completely, so some of the risks they take will have to be covered by their capital. This finding supports the motivation to create Basel II regulations that implement the minimum capital adequacy ratio to reduce risk-level [7]Therefore, in accordance with the moral hazard theory, we found that bank-risk taking behavior also has a negative effect on capital ratio, which indicates that when banks take more aggressive stance on risk-taking, they will decrease their capital ratio instead of increasing it because banks want to utilize available deposit insurance completely and avoid using their capital as protection measure. This result supports previous studies by [14]; [24]; [25]

Other findings from the regression result also support hypotheses 2 and 3 to show that both government-owned banks and foreign-owned banks take more risks than private-owned banks. Based on the asymmetric information theory, foreign-owned banks have less information regarding both the clients and the market itself, especially for the first few years. However, the reason behind more aggressive risk-taking behavior from foreign-owned banks could also be fueled by the difference in needs and objectives between the shareholders in home country and the managers in host country, as mentioned before in the agency theory [15]; [4]Moreover, in the context of Indonesia and Malaysia, foreign-owned bank tend to expect more revenue and opportunities in the future due to the rapid growth of the banking industry, therefore, they are willing to take more risks in return for more income and benefits in the future [12]; [13]; [26]Regression results also prove the political and social theory, which explain that stateowned banks are influenced by political interests which may differ from the bank's interests to gain more revenue. Banks with a political connection is also said to have the higher chance of getting covered and rescued by the government if they have problems. This finding is in line with previous studies by [12];[7] and [25]

Results of model 2 support hypotheses four which claims that foreign banks that enter the market via merger \& acquisition take less risk compared to those who enter via greenfield strategy. This finding is also in line with the asymmetric information theory and consistent with previous studies [27]; [2]The regression results also show that both state-owned and foreign-owned banks keep higher capital ratio compared to private-owned banks, proving hypotheses six right. State-owned banks have the responsibility to keep higher capital ratio as they need to keep the prudent principle [28] while foreign-owned banks have broader access to international investors and capital market, so it's easier for them to increase their capital anytime they want to [17]Finally, the regression results also support hypothesis $8 \mathrm{a}$ and $8 \mathrm{~b}$ and find that banks act differently by taking fewer risks and higher capital ratio during the financial crisis. As banks face insolvency risks during the time leading up to the crisis, banks tend to be less aggressive in taking risks to try and contain their risks level to avoid insolvency and at the same time increase their capital ratio to avoid having insufficient capital in case of a bank run. These results are also consistent with the findings from [17]; [21]However, previous studies also noted that the global financial crisis doesn't have a significant impact on banking industries in Southeast Asia, including Indonesia and Malaysia.

\section{c. Robustness Test}

Aside from the analysis of the estimated models, to ensure that all the findings within this study are consistent, we conducted a robustness test by using another proxy for dependent variables. We changed $\ln \mathrm{Z}$-Score, as the proxy for bank risk-taking behavior, with loans to deposit ratio [5]; [25] and changed the capital adequacy ratio, the proxy for capital ratio, with capital to asset ratio or capitalization [29]; [25]. We use the same method of simultaneous regression or 2SLS with random effects model to test the dependent variables and find similar results with the previous test. We found that bank risk-taking and capital ratio have a 
significant and negative effect to one another and that foreign-owned and state-owned banks take more risks and have higher capital ratio compared to private-owned banks while ownership concentration shows no relation to any of the dependent variables. Therefore, we can conclude that our findings are consistent.

\section{Conclusion}

This study found that bank risk-taking behavior and capital ratio has negative effect on one another, following the moral hazard theory. In terms of type of ownership, one of the findings also shows that both state-owned and foreign-owned banks take more risks and keep higher capital ratio level compared to private-owned banks, while foreign banks that enter the market via merger \& acquisition has higher bank-risk level compared to those who enter the market with greenfield strategy. This result implies that the Government could take more conservative decisions regarding foreign ownerships by implementing limitations on both foreign and government ownership to reduce overall risk level in the banking industry.

However, ownership concentration doesn't have any effect towards both bank risk-taking behavior and capital ratio based on our results. In addition, this study also proves that banks act differently by taking lower risks and keep higher capital ratio during the financial crisis period. Based on the findings, it would recommend the government to enact higher minimum capital adequacy ratio regulation and limit the ownership of both state and foreign investors if the government wants to lower the banking industry's overall insolvency risk level and provide a guideline of how banks in Indonesia and Malaysia acts during the financial crisis period.

\section{References}

[1] Y. Altunbas, S. Carbo, E. P. M. Gardener, and P. Molyneux, "Examining the Relationships between Capital, Risk and Efficiency in European Banking Examining the Relationships between Capital, Risk and Efficiency in European Banking," vol. 13, no. 1, pp. 1-20, 2007.

[2] D. H, H. O, J. E, and K. S, "Foreign bank entry, credit allocation and lending rates in emerging markets: Empirical evidence from Poland. Journal of Banking and Finance, 36(11), 2949-2959.," 2012.

[3] F. B, H. I, and W. Q, "Do corporate boards affect firm performance? New evidence from the financial crisis. Bank of Finland Research Discussion Papers, 11.," 2012.

[4] J. M C and M. W H, "Theory of the Firm: Managerial Behavior, Agency Costs and Ownership Structure. Journal of Financial Economics, 3(4), 305-360. https://doi.org/http://dx.doi.org/10.1016/0304-405X(76)90026-X," 1976.

[5] C. P, S. Jumreornvong, and J. P, "Basel III, capital stability, risk-taking, ownership: Evidence from Asia. Journal of Multinational Financial Management, 28, 28-46.," 2014.

[6] E. K M, "Agency Theory: An Assessment and Review Linked references are available on JSTOR for this article: Agency Theory: An Assessment and Review. The Academy of Management Review, 14(1), 57-74.," 1989.

[7] R. R and H. J A, "Ownership structure, risk and their impact towards performances in Indonesian commercial banks. Finance and Banking Journal.," 2013.

[8] A. Y, C. S, G. E P M, and M. P, "Examining the Relationships between Capital , Risk and Efficiency in European Banking, 13(1), 1-20.," 2007. 
[9] B. J H, D. N. G, and J. A M, "Bank Risk-Taking and Competition Revisited: New Theory and New Evidence. IMF Working Papers, 06(297), 1.," 2006.

[10] L. N, S. H, B. M, and A. R, "Research in International Business and Finance The impact of state and foreign ownership on banking risk : Evidence from the MENA countries, 36, 167-178.," 2016.

[11] S. A and V. R W, "Large Shareholders and Corporate Control, 94(3), 461-488.," 1986.

[12] Y. F., Rokhimawan, M. A., "Pengembangan Modul Pembelajaran Sains Berbasis Integrasi Islam-Sains untuk Peserta Didik Difabel Netra MI/SD Kelas 5 Semester 2 Materi Pokok Bumi dan Alam Semesta.," 2013.

[13] S. M and J. G A, "The effects of ownership change on bank performance and risk exposure: Evidence from indonesia. Journal of Banking and Finance, 0, 1-15.," 2014.

[14] A. A, C. G S, G. D, M. G S, and Z. J K, "Government intervention, bank ownership and risk-taking during the Indonesian financial crisis. Pacific Basin Finance Journal, 30, 114 131.," 2014.

[15] C. M, W. J, J. B N, and W. R, "Do foreign banks take more risk? Evidence from emerging economies. Journal of Banking and Finance, 82, 20-39.," 2017.

[16] de H. R and van L. I, "Foreign banks and credit stability in Central and Eastern Europe. A panel data analysis. Journal of Banking and Finance, 30(7), 1927-1952.," 2006.

[17] B. A, N. Clarke, G R G, R. CULL, K. L, and U. G F, "Berger, A. N., Clarke, G. R. G., Cull, R., Klapper, L., \& Udell, G. F. (2005). Corporate governance and bank performance: A joint analysis of the static, selection, and dynamic effects of domestic, foreign, and state ownership. Journal of Banking and Finance, 29(8-9 SPEC. ISS.), 2179-2221. Bitar, M., Pukthuanthong, K., \& Walker, T. (2017). The effect of capital ratios on the risk, efficiency a," 2005.

[18] N. E and B. U, "Market discipline, disclosure and moral hazard in banking. Journal of Financial Intermediation, 15(3), 332-361.," 2006.

[19] L. L and L. R, "Bank governance, regulation and risk taking. Journal of Financial Economics, 93(2), 259-275.," 2009.

[20] S. H and M. M, "Mekanisme Corporate Governance, KualitasLaba dan Nilai Perusahaan. Simposium Nasional Akuntansi 9 Padang, (61), 23-26.," 2006.

[21] A. Demirgüç-Kunt and E. Detragiache, "Does deposit insurance increase banking system stability? An emperical investigation. Journal of Monetary Economics, 49(7), 13731406.," 2002.

[22] Viverita and I. A, "Deposit insurance, crisis, and risk taking in ASEAN banks. International Journal of Economics and Management, 11(SpecialIssue1), 207-221.," 2017.

[23] I. G, N. G, and S. A, "The impact of government ownership on bank risk. Journal of Financial Intermediation, 22(2), 152-176.," 2013.

[24] Z. Y, Z. J, and Z. N, “Audit committee quality, auditor independence, and internal control weaknesses. Journal of Accounting and Public Policy, 26 (3), 300-327.," 2007.

[25] Z. C, M.-U.-H. S, R. M M, and A. B N, "Does the ownership structure matter for banks' capital regulation and risk-taking behavior? Empirical evidence from a developing country. Research in International Business and Finance, 42(July), 404-421.," 2017.

[26] T. I, A. A, and T. A, "Why have bank interest margins been so high in Indonesia since the 1997/1998 financial crisis? Research in International Business and Finance, 32, 139$158 ., " 2014$. 
[27] Chen, VZ, L. J, and S. DM, "Are OECD-prescribed 'good corporate governance practices' really good in an emerging economy? Asia Pacific Journal of Management, 28 (1), 115-138.," 2011.

[28] C. G, X. L, and F. M, "Chen, G., Firth, M., \& Xu, L. (2009). Does the type of ownership control matter? Evidence from China's listed companies. Journal of Banking and Finance, 33(1), 171-181.," 2009.

[29] L. C C and H. M F, "The impact of bank capital on profitability and risk in Asian banking. Journal of International Money and Finance, 32(1), 251-281.," 2013. 


\section{APPENDIX}

Table 4.2. Effect of Capital Ratio, Ownership Type and Concentration towards Bank Risk Taking Behavior, using simultaneous regression (2SLS)

\begin{tabular}{|c|c|c|c|c|c|c|}
\hline \multirow{4}{*}{$\begin{array}{l}\text { Dependent Variable } \\
\text { Independent Variable }\end{array}$} & \multicolumn{2}{|c|}{ Lnzscore (Model 1) } & \multicolumn{2}{|c|}{ Lnzscore (Model 2) } & \multicolumn{2}{|c|}{ Capital Adequacy Ratio } \\
\hline & Full Model & Crisis Model & Full Model & Crisis Model & Crisis Model & Full Model \\
\hline & \multicolumn{6}{|c|}{ Random Effects $2 S L S$} \\
\hline & Coef. & Coef. & Coef. & Coef. & Coef. & Coef. \\
\hline Constanta & 0,3635 & 0,3936 & 0,3554 & $0,3902 * *$ & $1,6885 * * *$ & $1,3056 * * *$ \\
\hline$C A R$ & $1,3870 * * *$ & $1,3930 * * *$ & $1,3451 * * *$ & $1,3535 * *$ & & \\
\hline Inzscore & & & & & $0,2779 * * *$ & $0,2914 * * *$ \\
\hline Foreign & $-0,3541 * * *$ & $-0,3570 * * *$ & $-0,5606 * * *$ & $-0,5506 * * *$ & $0,1501 * * *$ & $0,1527 * * *$ \\
\hline StateOwned & $-0,7642 * * *$ & $-0,7516 * * *$ & $-0,7703 * * *$ & $-0,7574 * * *$ & $0,2203 * * *$ & $0,2376 * * *$ \\
\hline$P S$ & $-2,0389$ & $-2,0105$ & $-2,1041$ & $-2,0720$ & 0,5290 & 0,5869 \\
\hline$A S$ & $-0,1178$ & $-0,1432$ & $-0,0826$ & $-0,1125$ & 0,0627 & 0,0636 \\
\hline MA & & & $0,3261 *$ & $0,3065 * * *$ & & \\
\hline Leverage & $-1,8174 * * *$ & $-1,6835 * * *$ & $-1,7895 * * *$ & $-1,6606$ & & \\
\hline RWATA & & & & & $-0,2618 * * *$ & $-0,2563 * * *$ \\
\hline$R O A$ & & & & & $0,3458 *$ & $0,4055 * *$ \\
\hline$A G$ & & & & & 0,0054 & $-0,0016$ \\
\hline Size & $0,2322 * * *$ & $0,2182 * * *$ & $0,2329 * * *$ & $0,2189 * * *$ & $-0,1153 * * *$ & $-0,0981 * * *$ \\
\hline GGDP & $5,8884 * *$ & $9,8485 * * *$ & $5,7256 * *$ & $9,5785 * * *$ & $-1,2230 *$ & $-2,3455 * *$ \\
\hline INFL & $-0,6660$ & $-1,8833 * *$ & $-0,6134$ & $-1,8003$ & $-0,3503$ & 0,0819 \\
\hline Crisis & & $0,2598 * * *$ & & $0,2520 *$ & & $-0,0600 *$ \\
\hline No. Observasi & 1199 & 1199 & 1196 & 1196 & 1197 & 1197 \\
\hline Prob $>$ Chi & 0,0000 & 0,0000 & 0,0000 & 0,0000 & 0,0000 & 0,0000 \\
\hline R-sq within & 0,1234 & 0,1269 & 0,1271 & 0,1303 & 0,0874 & 0,0769 \\
\hline R-sq between & 0,0218 & 0,0251 & 0,0240 & 0,0273 & 0,3412 & 0,3151 \\
\hline R-sq overall & 0,0638 & 0,0696 & 0,0666 & 0,0722 & 0,1907 & 0,1680 \\
\hline Significant at $10 \%$ & $*$ & & & & & \\
\hline Significant at 5\% & $* *$ & & & & & \\
\hline Significant at $1 \%$ & $* * *$ & & & & & \\
\hline
\end{tabular}

